Aboujaoude, director of the Impulse Control Disorders Clinic at the Stanford University School of Medicine in California, who laments the lack of biological data about the effects on the brain of human-technology interaction. "The science is just not there yet, unfortunately, for something that has so radically and irreversibly changed our lives," says Aboujaoude.

Some mental health experts are, however, trying to rectify that. For example, researchers from the National Health Insurance Corporation in Seoul, South Korea, have been using functional Magnetic Resonance Imaging to study neurophysiologic differences between hardcore and casual online gamers while observing video of the game World of Warcraft. Their initial findings, presented in May at the American Psychiatric Association's 162 nd annual meeting, suggest that activity in the frontal lobes of the brains of the study group (whose members played online games an average of eight hours a day) was significantly different than for the control group (whose members played online games an average of three hours a day), though the researchers admit they aren't yet sure how to interpret these results.

Although the scientific evidence is spotty and inconclusive, Aboujaoude, unlike Bell, believes Internet addiction is a real problem and that the Internet is not a typical communications medium. Unlike television or movies or print, the Internet is not inanimate. It communicates back, in a sense, allowing users to feel a sense of connectedness with others. But the ease and appeal of substituting virtual relationships for real-world friendships can be dangerous for some.

"By and large, these relationships tend to be superficial," says Aboujaoude. "They do not provide the kind of nurturing connectedness that will help you navigate your way through life. If social networking has replaced long-term, grounded friendships, that's a problem." - Roger Collier, CMAJ

\title{
Medical faculties decimated by violence in Iraq
}

Previously published at www.cmaj.ca

I raq's medical schools have been disproportionately targeted in the attacks on university faculties that have ensued since the 2003 invasion of Iraq by United States-led forces, says the Baghdad-based Iraqi Association of University Teachers.

Some 118 medical faculty members have since been murdered, according to Dr. Ismail Jalili, a London, Englandbased surgeon who conducted a detailed analysis of data from the teachers' association and the Iraq Body Count, a database of violence-related deaths compiled from morgue data, official health data and media reports.

About $30 \%$ of all assassinated faculty members came from the country's 12 medical schools, Jalili notes in a report describing "the targeted and systematic murder of academics, intellectuals and experts."

The murders appear motivated by sectarian politics or greed, Jalili says. "The killers seem to have targeted medical faculty because of their public importance and possibly because of their relative wealth."

The faculty killings peaked in 2006 and have dwindled over the past few years. But they reflect a broader ongoing disaster for the country's

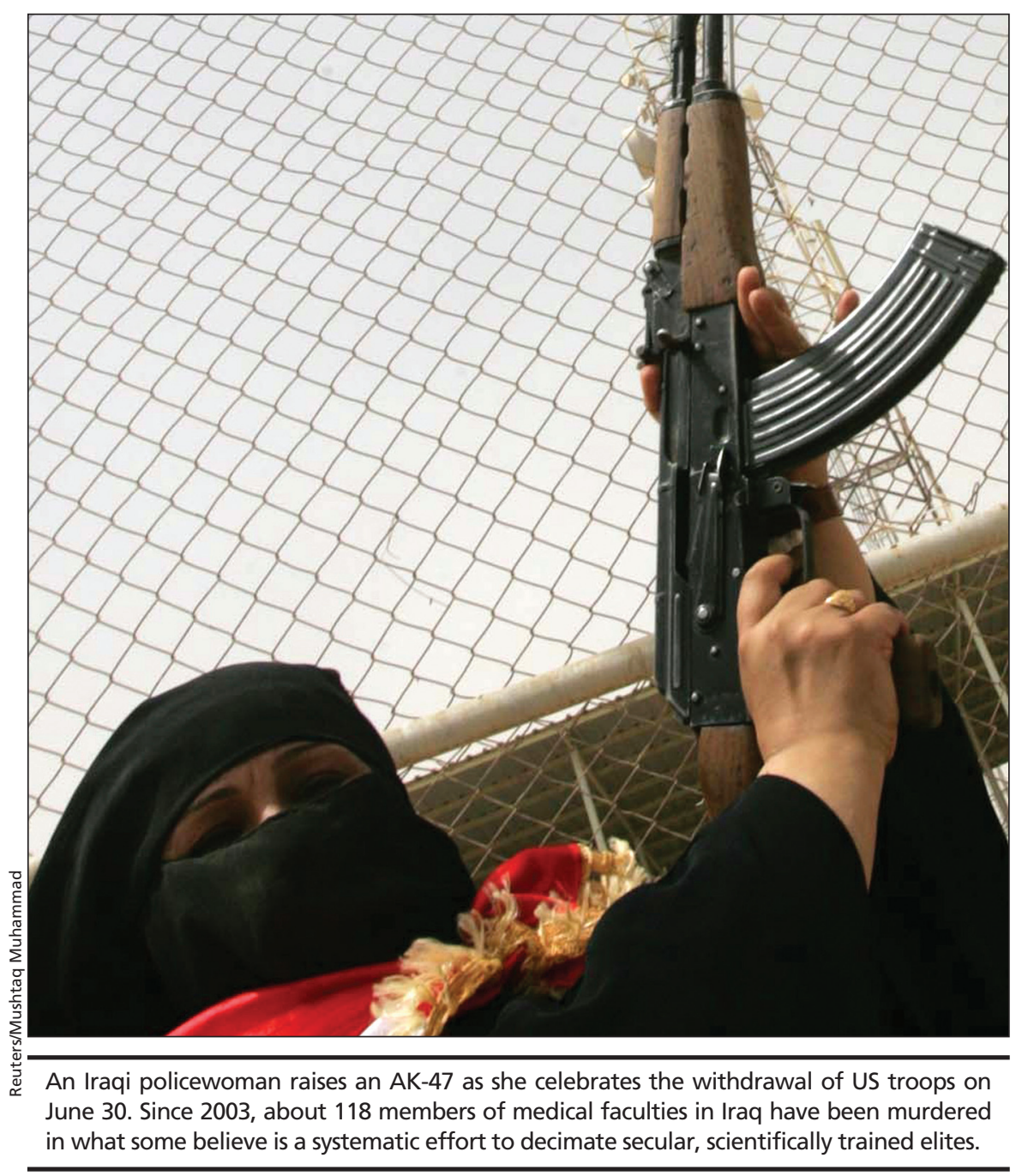


medical profession and the health of its residents. The Iraqi Medical Association estimates that 2000 of the 34 000 physicians working in Iraq before 2003 have been killed, while 18000 have fled. Government financial incentives and promises of protection have not persuaded many of the professional refugees to return.

The toll has been felt by all facets of the population. The Iraqi Ministry of Health attributed 151000 "excess" civilian deaths to the violence between 2003 and 2006, while a team of American and Iraqi epidemiologists pegged that tally even higher, saying that the number of deaths that would have been avoided had there been no invasion was actually 655000 (Lancet 2006;368: 1421-8).

Jalili believes the faculty attacks are part of a systematic effort to decimate secular, scientifically trained elites. "All universities in the conflict zone, from Mosul in the north to Basra in the south have had their share of murders with Baghdad's three universities being the worst hit."

In most cases, the killers were unknown gunmen, he says. "The commonest tactic is by prior threat, usually via letters hand delivered at home or work with a bullet enclosed with the letter, or by telephone to the victims; both methods calling for them to resign their post."

Those who resign escape targeted killing, Jalili found, but "when reemployed in a different location and just simply visiting their previous place of work, they were killed. Victims movements were therefore known to the culprits and victims had been under surveillance not only at home."

The motives vary, Jallili surmises. "Some could have been kidnappings for financial gain that went wrong. In others, it is likely there was a political motivation. This scenario matches similar incidents in the general population. It also fits the general pattern of killing which is possibly part of sectarian murders and/or ethnic cleansing. It is also possible that several of the initial assassinations were aimed against those who held important positions in the previous regime."

Dr. Jalal Al Mosawi, head of pedi- atrics at University Hospital in Al Kadhimiyia, Baghdad, and editor-in-chief of The New Iraqi Journal of Medicine, which is sponsored by the Ministry of Health, says the targeting of medical faculty may also represent an especially vicious form of academic infighting. "All of the university deans and presidents were appointed by [former Iraqi dictator Saddam Hussein], and not usually for their academic credentials. Many people were assassinated for cooperating with Saddam, and many others were assassinated for cooperating with the Americans."

After attention was drawn to the murders of medical faculty and physicians by United Nations officials, US occupational authorities and the Government of Iraq agreed to provide protection, says Amer al-Khuzaie, an official responsible for physician security efforts at the Iraqi Ministry of Health in Baghdad.

"The Ministry of Health studied the issue and decided to supply each specialist with two guards from the Ministry of the Interior," al-Khuzaie says. "We also transferred many physicians' private clinics to hospitals, and have issued licences for weapons to those who wish to and can protect themselves. Security has now improved."

Although sectarian violence has flared in several Iraqi cities in recent months with the withdrawal of US troops, officials are hopeful that the country will not slide back into civil war.

"The security conditions are still hectic," says Dr. Zakaria Arajy, head of postgraduate studies in reconstructive surgery at the University of Baghdad School of Medicine. "The overall state has improved as compared to 2006 2007, but our lives are not secure. And there is little improvement in the medical services delivered to the patients."

Despite the violence, Iraqi health officials say conditions are improving but still desperate. Under-five mortality rates (46 per 1000) and maternal mortality rates (84 per 100 000) are far higher than in neighbouring countries, and higher than they were before the invasion. One in eight deaths is violence-related. Roughly $38 \%$ of pregnant women are anemic. Diarrhea and acute respiratory infections - further compounded by malnutrition - account for about twothirds of deaths amongst the under-five population. UNICEF estimates that only one in three Iraqi children under the age of five has access to safe drinking water, while $14 \%$ of children are born underweight.

The Iraq Medical Association says $90 \%$ of the almost 180 hospitals in Iraq lack essential equipment, causing high numbers of avoidable deaths. Meanwhile, Marie Fernandez, a spokeswoman for the Vienna-based aid agency Saving Children from War, says vital supplies are desperately lacking. "Children are dying because there are no blood bags available."

Although the US government has spent nearly US\$40 billion on Iraqi reconstruction projects, only about US\$1 billion has been devoted to

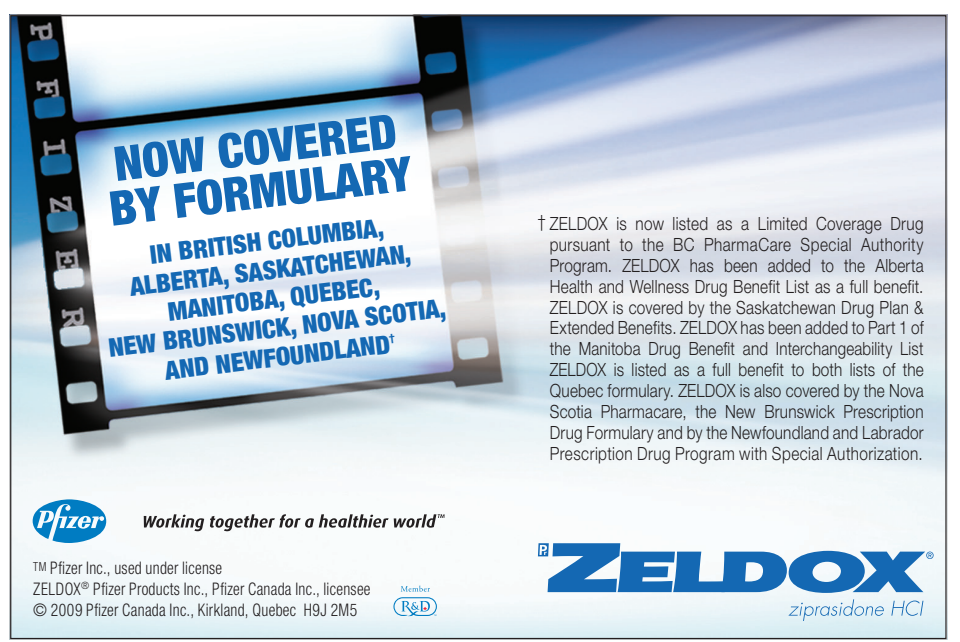


health care facilities, mostly on primary health care. According to US auditors, much of that money was misspent by US contractors and many of the primary health centre projects were not completed.

The situation is less grim in Kurdistan, a northern region where a proAmerican local government prevented violence from flaring after the occupation. With a booming economy driven by investment from foreign energy companies, the three Kurdish provinces have total budgets of US $\$ 2.5$ billion, matching the combined budget of Iraq's other 15 provinces. Some health indicators "show strong improvement," says Abdelrahman Younis, the regional health minister. Infant mortality and under-five mortality have both been halved since 2006.

At the Sulaimaniyah Emergency Hospital, the largest in the Kurdish province of Sulaimaniyah, orthopedic surgeon Dr. Affan Hamakhan Jafar says public health is improving, partly because health policies have become more coherent as violence and feuding between Kurdish political factions subsides. Dr. Manana Anjaridze, a Soviet-trained physician who manages a 96-bed burn hospital in Sulaimaniyah funded by Médecins Sans Frontières, says that his facility was once flooded by patients from other provinces but growing stability outside Kurdistan is calming the crisis.

That assessment - that the bloodbath has ceased but conditions for medical faculty remain extremely precarious - is echoed by Ahmed Khedr, a physicist at Baghdad's Al-Nahrain University who stepped in to head the Association of University Teachers after his predecessor was murdered.

"There remains some targeting of university teachers in some provinces," says Khedr. "It continues for political reasons."

Physicians have been caught between factions involved in fighting, and attacked from all sides, he adds. "The attacks have been systematic, widespread and devastating. But we never get evidence from these assassinations that we can use to seek justice." - Paul Webster, Sulaymaniyah, Iraq

DOI:10.1503/cmaj.109-3035

\section{More news at cmaj.ca}

C $M A J$ health news is now online daily as part of the journal's move to electronic publishing. The shift allows us to provide more stories to readers, on a more timely basis, while also publishing more Dispatches from the Medical Front. The following represents some of the pieces which have been posted at www.cmaj.ca since the last print edition of the journal.

Mobility: Provincial medical regulatory colleges are struggling to find consensus on a new set of rules to govern the mobility of doctors in Canada. - Ann Silversides, CMAJ

Travelling pets: Air Canada's recent decision to rescind its ban on small pets travelling in airplane passenger cabins compromises the health of allergy and asthma sufferers, says the Canadian Lung Association. - Dan Lett, Winnipeg, Man.

Restart: Inpatient programs to treat Internet addiction are becoming increasingly common but there is little scientific evidence to prove that they work. - Roger Collier, CMAJ

\section{Airports flu risks: Airports in Toronto and Vancouver act as major gateways for infectious diseases and the federal government must better manage health risks arising from international air travel, warns a landmark report prepared for the Public Health Agency of Canada. - Paul Webster, Toronto, Ont.}

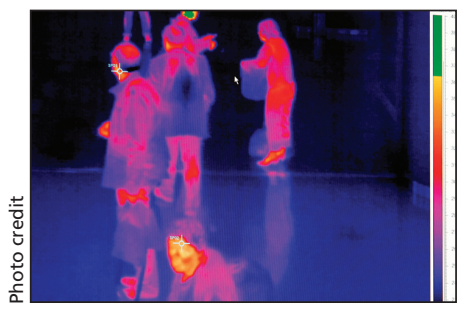

Patterns: The pandemic (H1N1) 2009 virus remains alive on the eighth day in $8 \%-13 \%$ of people after they develop flu symptoms, a team of Quebec researchers has determined. - Laura Eggertson, Ottawa, Ont.

Tales from the trenches: A pair of Toronto hospital administrators describe their experiences in containing Clostridium difficile rates within their facilities. - Ann Silversides, CMAJ

Antiviral access: The federal government is contemplating measures that would provide quicker access to antivirals for residents of remote communities facing pandemic (H1N1) 2009 outbreaks. - Wayne Kondro, CMAJ

Outbreak: The first pandemic (H1N1) 2009 outbreak of Canada's fall flu season has occurred, in remote Aboriginal communities on Vancouver Island in British Columbia. - Wayne Kondro, CMAJ

\section{Dispatches}

Short-lived joy: A northern physician grapples with inequality, and the weight of fluids, while working abroad. - AnneMarie Pegg MD, Yellowknife, NWT

Tomatoes and ideas: A Northwest Territories physician muses on her first experience attending the Canadian Medical Association's General Council. - Amy Hendricks MD, Yellowknife, NWT

DOI:10.1503/cmaj.109-3061 cmaj.ca 